\title{
Pola Konsumsi Pangan Hewani pada Rumahtangga di Propinsi Sumatera Barat (Penerapan Model Almost Ideal Demand System)
}

\section{Household Pattern of Animal Food Consumption in West Sumatera Province (Application of Almost Ideal Demand System Model)}

\author{
A. P. Ermanda ${ }^{1 *}$, Jafrinur ${ }^{2}$, dan J. Hellyward ${ }^{2}$ \\ ${ }^{1}$ Program Studi Magister Peternakan, Fakultas Peternakan, Universitas Andalas, Padang \\ ${ }^{2}$ Program Studi Peternakan, Fakultas Peternakan, Universitas Andalas, Padang \\ *E-mail: adliputraermanda@gmail.com
}

(Diterima: 26 April 2019; Disetujui: 14 Juli 2019)

\begin{abstract}
ABSTRAK
Penelitian ini bertujuan untuk mengetahui pola konsumsi pangan hewani terutama daging sapi, unggas dan ikan pada rumahtangga di Propinsi Sumatera Barat. Penelitian ini memakai pendekatan ekonometrika dengan membangun model fungsi permintaan untuk komoditas daging sapi, daging unggas dan ikan dengan memakai data mentah hasil Survei Sosial Ekonomi Nasional (SUSENAS) untuk Propinsi Sumatera Barat Tahun 2018. Jumlah sampel penelitian sebanyak 100 rumahtangga. Data dianalisis dengan menggunakan model Almost Ideal Demand System (AIDS). Variable yang digunakan didalam model, yaitu harga daging sapi, harga daging unggas, harga ikan, total pengeluaran rumah tangga, jumlah anggota rumah tangga, umur ibu rumah tangga, dummy pendidikan ibu rumah tangga (berpendidikan tinggi, berpendidikan rendah), dan dummy wilayah (kota, desa). Pola konsumsi dari permintaan daging sapi, daging unggas dan ikan ditandai dengan R2 bernilai 0,8233 , artinya $82,33 \%$ dari variabel yang digunakan dalam model dapat menjelaskan keragaman pola konsumsi daging sapi, unggas dan ikan di Propinsi Sumatera Barat dan sisanya sebesar $18,62 \%$ tidak dapat dijelaskan oleh variabel yang digunakan dalam model.
\end{abstract}

Kata kunci: pangan hewani, pola konsumsi, rumahtangga, Sumatera Barat

\section{ABSTRACT}

This study aims to determine patterns of consumption of animal foods, especially beef, poultry and fish in households in West Sumatra Province. This study used an econometric approach by building a model of demand function for beef, poultry and fish commodities using raw data from the results of the National Socio-Economic Survey (SUSENAS) for West Sumatra Province in 2018. The total sample was 100 households. Data were analyzed using the Almost Ideal Demand System (AIDS) model. Variables used in the model, namely beef prices, poultry meat prices, fish prices, total household expenses, number of household members, age of housewives, dummy education of housewives (highly educated, low educated), and dummy area (city, village). The consumption pattern of demand for beef, poultry meat and fish is indicated by $R 2$ valued at 0.8233 , meaning $82.33 \%$ of the variables used in the model can explain the diversity of patterns of consumption of beef, poultry and fish in West Sumatra Province and the remaining $18.62 \%$ cannot be explained by variables used.

Keywords: animal food, consumption pattern, household, West Sumatera 


\section{PENDAHULUAN}

Masalah kecukupan pangan dan gizi adalah suatu hal yang sangat penting sekali oleh karena itu pembangunan pertanian dan peternakan diarahkan untuk memenuhi kecukupan pangan dan gizi masyarakat yang dapat tercermin dari kecukupan kalori dan protein. Kebutuhan kalori bisa didapatkan dari makanan pokok, sedangkan kebutuhan protein lebih banyak didapatkan dari konsumsi makanan hewani seperti daging, telur, susu dan ikan (Jafrinur, 2006).

Widyakarya Nasional Pangan dan Gizi (WNPG) yang merupakan forum lintas pemangku kepentingan yang berperan secara strategis dalam upaya mempertemukan dan mensinkronisasikan berbagai program serta kebijakan pangan dan gizi telah melakukan pertemuan ke-XI yang diadakan pada tanggal 3 Juli 2018 telah menetapkan bahwa patokan kecukupan konsumsi kalori dan protein per kapita per hari yaitu sebesar $2.100 \mathrm{kkal}$ dan 57 gram per kapita per hari (Tabel 1).

Maka rata-rata konsumsi kalori dan protein masyarakat Indonesia secara nasional yang sebesar 1.868,77 kkal dan 54,16 gram masih berada dibawah standar yang ditetapkan oleh WNPG dan untuk Propinsi Sumatera Barat sendiri, rata-rata angka kecukupan konsumsi kalori dan protein per kapita per hari yaitu sebesar 1.922,08 kkal dan 51.67 gram per kapita per hari, yang berarti juga masih dibawah standar WNPG dan rata-rata konsumsi kalori dan protein secara nasional.

Kondisi konsumsi daging yang masih rendah di Propinsi Sumatera Barat ternyata berbanding terbalik dengan jumlah produksi daging sapi 23.782 ton/tahun dan daging unggas sebanyak 40.895 ton/tahun, jika diakumulasikan maka total kedua daging tersebut berjumlah 64.678 ton/tahun serta ditambah produksi ikan sebesar 269.123 ton/tahun maka dapat dikatakan jumlah produksi daging sapi, daging unggas dan ikan tergolong cukup tinggi. Seharusnya dengan jumlah produksi daging yang tinggi tersebut dapat memenuhi target konsumsi kalori dan protein yang ditetapkan oleh WNPG karena mengingat jumlah penduduk Propinsi Sumatera Barat yang sebanyak 5.259.528 jiwa. (Badan Pusat Statistik Sumatera Barat, 2018)

Menurut teori ekonomi, pola konsumsi dipengaruhi oleh banyak variabel terhadap suatu komoditas, diantaranya harga barang itu sendiri, harga barang lain yang terkait, pendapatan per kapita, selera atau kebiasaan, jumlah penduduk, prediksi harga di masa depan, distribusi pendapatan dan usaha-usaha produsen meningkatkan penjualan. Dalam rangka peningkatan konsumsi masyarakat terhadap komoditas ternak diperlukan informasi tentang faktor-faktor yang menentukan konsumsi masyarakat terhadap komoditas ternak.

Berdasarkan kondisi di atas, untuk mengungkap fenomena rendahnya konsumsi daging di Propinsi Sumatera Barat dipandang perlu untuk melakukan penelitian yang bertujuan untuk menemukan variabelvariabel yang menentukan pola konsumsi daging di Propinsi Sumatera Barat. Dimana pada penelitian ini disamping memasukkan variabel ekonomi juga akan memasukkan

Tabel 1. Perbandingan Konsumsi Kalori dan Protein di Propinsi Sumatera Barat dan Nasional dengan WNPG (Widyakarya Nasional Pangan dan Gizi)

\begin{tabular}{lcc}
\hline Wilayah & $\begin{array}{c}\text { Konsumsi Kalori } \\
(\text { Kkal/Kapita/Hari) }\end{array}$ & $\begin{array}{c}\text { Konsumsi Protein } \\
(\mathrm{gr} / \text { Kapita/Hari })\end{array}$ \\
\hline WNPG & $2.150,00$ & 57,00 \\
Nasional & $1.868,77$ & 54,16 \\
Sumatera Barat & $1.922,08$ & 51,67 \\
\hline
\end{tabular}

Sumber: Data diolah peneliti 2017 
variabel non ekonomi berupa variabel-variabel sosiodemografi sebagai variabel yang diduga juga mempengaruhi pola konsumsi seseorang terhadap daging dan bagaimana pengaruh variabel-variabel terhadap konsumsi daging jika terjadi perubahan pada variabel-variabel yang bersangkutan.

Tujuan penelitian ini adalah untuk mengetahui (1) Pola konsumsi daging sapi, daging unggas dan ikan pada rumah tangga di Provinsi Sumatera Barat, dan (2) Faktor - faktor apa saja yang mempengaruhi permintaan daging sapi, daging unggas dan ikan pada rumah tangga di Provinsi Sumatera Barat.

Sehingga secara akademis penelitian ini dapat menjadi bahan masukan berupa sumbangan data dan informasi bagi peneliti, ataupun pihak lainnya yang memerlukan terutama informasi tentang daging sapi, daging unggas dan ikan untuk dijadikan referensi dan wacana penelitian selanjutnya yang lebih mendalam serta secara praktis penelitian ini dapat menjadi bahan pertimbangan bagi pemerintah dan pihakpihak yang terlibat dalam sistem distribusi dan agribisnis daging sapi, daging unggas dan ikan untuk mengetahui apa yang diinginkan dan dibutuhkan konsumen serta melakukan serangkaian perbaikan yang diperlukan dalam bidang konsumsi terutama daging sapi, daging unggas dan ikan pada rumahtangga di Propinsi Sumatera Barat.

\section{METODE}

\section{Lokasi Penelitian}

Penelitian dilaksanakan di Kota Padang dengan mendatangi langsung Kantor Badan Pusat Statistik (BPS) Sumatera Barat di jalan Khatib Sulaiman, Kota Padang, Propinsi Sumatera Barat.

\section{Jenis dan Sumber Data}

Penelitian ini menggunakan data mentah (row data) yang merupakan hasil dari Survei Sosial Ekonomi Nasional pada edisi Maret 2018 yang diperoleh dari Badan
Pusat Statistik (BPS). Data SUSENAS sendiri tidak dipublikasikan secara terbuka atau umum, melainkan harus didapatkan dengan mengambil data melalui forum khusus pada website resmi Badan Pusat Statistik dan harus menyelesaikan serangkaian persyaratan untuk mendapatkan data tersebut.

Data yang telah terkumpul kemudian dipilah sesuai kebutuhan pada variabel yang digunakan pada penelitian ini hingga didapatkan rumahtangga yang memenuhi karakteristik untuk selanjutnya digunakan sebagai sampel penelitian ini. Data yang didapatkan dari SUSENAS menampilkan 10.067 rumahtangga yang telah disurvei oleh Badan Pusat Statistik dengan variabel yang dibutuhkan untuk melakukan penelitian ini dan selanjutnya dianggap sebagai populasi.

Dengan jumlah populasi yang terlalu besar maka jumlah data untuk dijadikan sampel penelitian perlu diperkecil lagi dengan menggunakan Rumus Slovin, Rumus Slovin digunakan untuk menghitung jumlah sampel dikarenakan populasi penelitian dianggap telah homogen dan Badan Pusat Statistik sebagai instansi pengambil dan pengolah data juga dianggap telah melakukan sampling yang baik. Rumus perhitungan Slovin tertera sebagai berikut:

$$
\mathrm{n}=\frac{\mathrm{N}}{1+\mathrm{N}(\mathrm{e})^{2}}
$$

dimana :

$\mathrm{n}$ = Ukuran sampel penelitian

$\mathrm{N}=$ Populasi rumah tangga dari data SUSENAS

$\mathrm{e}=$ margin error (dalam penelitian ini digunakan 10\%)

Berdasarkan rumus tersebut maka jumlah responden dalam penelitian ini adalah:

$$
\mathrm{n}=\frac{10.000}{1+10.000(0.01)}=100
$$

Maka dalam penelitian ini digunakan 100 rumahtangga yang selanjutnya akan digunakan sebagai sampel penelitian. 


\section{Variabel Penelitian}

Untuk menjawab tujuan penelitian, maka variabel yang digunakan adalah sebagai berikut:

Berdasarkan faktor ekonomi:

1. Jumlah konsumsi daging sapi (Kg/RT/ Minggu)

2. Jumlah konsumsi daging unggas ( $\mathrm{Kg} / \mathrm{RT} /$ Minggu)

3. Jumlah konsumsi ikan (Kg/RT/Minggu)

4. Harga daging sapi $(\mathrm{Rp} / \mathrm{Kg})$

5. Harga daging unggas $(\mathrm{Rp} / \mathrm{Kg})$

6. Harga ikan $(\mathrm{Rp} / \mathrm{Kg})$

7. Pendapatan rumahtangga ( $\mathrm{Rp} /$ bulan)

Berdasarkan faktor non-ekonomi:

1. Jumlah anggota rumahtangga (orang)

2. Umur ibu (tahun)

3. Dummy pendidikan ibu

Dummy Pendidikan;

1: Ibu lulus perguruan tinggi

0 : Ibu tidak lulus perguruan tinggi

4. Wilayah tempat tinggal rumahtangga

Dummy wilayah tempat tinggal;

$1:$ wilayah perkotaan

0 : wilayah perdesaan

\section{Metode Penelitian}

Penelitian ini bersifat desk study karena penelitian ini menggunakan data sekunder yang didapatkan dari hasil Survei Sosial Ekonomi Nasional (SUSENAS) yang dilakukan oleh Badan Pusat Statistik. Desk study sendiri berarti yaitu metode pengumpulan data berupa laporan-laporan studi terdahulu, paper atau makalah, serta data sekunder yang dibutuhkan dalam mendisain riset, serta menganalisis hasil studi. Pada penelitian ini digunakan bantuan komputer dengan software SAS dan Microsoft Office Excel 2007.

Model matematika yang digunakan adalah model Almost Ideal Demand System (AIDS) yang dikembangkan oleh Deaton and Muellbauer (1980) yaitu sebagai berikut:
$\mathrm{W}_{\mathrm{i}}=\alpha_{\mathrm{i}}+\log \mathrm{P}_{\mathrm{i}}+\beta_{\mathrm{i}} \log +\theta_{\mathrm{a}} \log \mathrm{JK}+\theta_{\mathrm{b}} \log$ $\mathrm{U}+\theta_{\mathrm{c}} \log \mathrm{Pddk}+\theta_{\mathrm{d}} \log \mathrm{W}+\mathrm{u}_{\mathrm{i}}$

Keterangan :

$\mathrm{Wi}=$ Share/Proporsi pengeluaran daging ke- $\mathrm{i}$ terhadap totalpengeluaran daging $(\mathrm{i}=$ $1,2,3$,

$\mathrm{Pj}=$ Harga agregat dari komoditas pangan hewani ke-j $(\mathrm{j}=1,2,3$,

$\mathrm{x}=$ Pengeluaran total untuk pangan hewani rumahtangga

$\mathrm{P}^{*}=$ Indeks harga stone (indeks harga stone dicari dengan rumus: $\log \mathrm{p}^{*}=\Sigma \mathrm{w}_{\mathrm{i}} \log$ $\left.\mathrm{p}_{\mathrm{i}}\right)$

$\mathrm{JK}=$ Jumlah anggota rumahtangga (orang)

$\mathrm{U}=$ Umur Ibu Rumahtangga (tahun)

Pddk = Dummy Pendidikan Ibu rumahtangga (tahun)

$1=$ jika ibu lulusan Perguruan Tinggi

$0=$ jika ibu tidak lulusan Perguruan Tinggi

$\mathrm{W}=$ Dummy wilayah tempat tinggal rumahtangga

$1=$ Perkotaan

$0=$ Perdesaan

$\alpha, \beta, \gamma=$ Parameter regresi berturut-turut untuk intersep, pengeluaran dan harga agregat untuk masingmasing komoditas.

$\theta_{\mathrm{a}}, \theta_{\mathrm{b}}, \theta_{\mathrm{c}}, \theta_{\mathrm{d}}=$ parameter regresi berturutturut untuk jumlah anggota rumahtangga,umur ibu, dummy pendidikan ibu rumahtangga, dan dummy pekerjaan ibu rumahtangga.

$\mathrm{u}_{\mathrm{i}}=$ faktor kesalahan

HASIL DAN PEMBAHASAN

Pola Konsumsi Pangan Hewani Daging Sapi, Unggas dan Ikan pada Rumahtangga di Propinsi Sumatera Barat

Untuk melihat pola konsumsi ketiga jenis daging tersebut dilihat dari variable yang 
mempengaruhinya yaitu:

a. Harga Daging Sapi, Harga Unggas dan Harga Ikan

Pengeluaran rumah tangga yang terbesar adalah daging sapi ( $R p$ 68.800/ minggu) dengan jumlah konsumsi sebesar $0,669 \mathrm{~kg} / \mathrm{RT} / \mathrm{minggu}$, namun jumlah konsumsi daging sapi lebih rendah apabila dibandingkan dengan jumlah konsumsi daging unggas dan ikan (Tabel 2).

Hal ini terjadi diperkirakan karena harga daging sapi yang cenderung lebih mahal daripada daging unggas dan ikan, hal ini sesuai dengan pendapat Hardjosworo (2010) bahwa salah satu faktor penting penyebab rendahnya konsumsi protein hewani adalah mahalnya harga pangan asal ternak bila diukur dari ratarata pendapatan sebagian besar masyarakat Indonesia.

b. Pendapatan Rumahtangga

Strata pendapatan pada penelitian ini di ranking menggunakan kriteria Bank Dunia, yang mengelompokkan pendapatan dalam tiga strata. Setelah di ranking, kelompok rumah tangga pendapatan rendah adalah $40 \%$ sampel pengeluaran terbawah yaitu rata-rata pengeluarannya sebesar $\mathrm{Rp}$ 1.255.583 kelompok pendapatan tinggi adalah $20 \%$ pendapatan tertinggi dengan rata-rata pengeluaran sebesar $\mathrm{Rp}$ 8.300.424 dan sisa diantaranya (40\%) adalah kelompok pendapatan sedang dengan rata-rata pengeluaran sebesar Rp 2.863.430. Dalam analisis, tingkat pendapatan diproksi dengan tingkat pengeluaran rumahtangga (Tabel 3).

Pada rumah tangga berpendapatan rendah pangsa pengeluaran paling tinggi untuk pangan. Makin tinggi strata pendapatan, makin kecil pula pangsa pengeluaran untuk pangan, dan sebaliknya pangsa pengeluaran untuk non pangan lebih tinggi pada rumah tangga berpendapatan tinggi. Pada rumahtangga strata pendapatan tinggi ini, kebutuhan untuk pangan sudah tercukupi sehingga rumahtangga ini beralih ke kebutuhan lain untuk gaya hidup dan kesenangan, misalnya untuk membeli barang mewah sehingga dapat meningkatkan taraf hidup atau status sosial dihadapan orang lain.

c. Jumlah Anggota Rumahtangga

Rumah tangga dengan jumlah anggotanya kecil dari 3 orang berjumlah 41 rumah tangga (41\%), untuk rumah tangga dengan jumlah anggotanya 4-5 adalah 42 rumah tangga (42\%) dan untuk rumah tangga dengan jumlah anggotanya lebih dari 6 orang adalah 17 rumah tangga (17\%) (Tabel 4).

Dari data diatas dapat disimpulkan bahwa semakin besar jumlah anggota rumahtangga juga semakin mempengaruhi peningkatan pangsa pengeluaran yang dikeluarkan untuk kebutuhan pangan, hal ini dikarenakan uang yang didapatkan setiap bulannya akan lebih diprioritaskan untuk kebutuhan pemenuhan pangan setiap anggota rumahtangga. Namun, rumahtangga dengan pangsa pengeluaran untuk pangan yang tinggi, tidak meningkatkan jumlah konsumsi daging per kapitanya. Hal ini disebabkan karena jumlah daging yang dibeli akan dikonsumsi oleh jumlah anggota rumahtangga yang banyak.

Sebaliknya, apabila anggota rumahtangga sedikit maka pangsa pengeluaran

Tabel 2. Pola konsumsi daging berdasarkan harga daging

\begin{tabular}{lccc}
\hline $\begin{array}{l}\text { Jenis Komoditi } \\
\text { Daging }\end{array}$ & $\begin{array}{c}\text { Konsumsi } \\
(\mathrm{kg} / \mathrm{RT} / \mathrm{minggu})\end{array}$ & $\begin{array}{c}\text { Harga } \\
(\mathrm{Rp} / \mathrm{kg})\end{array}$ & $\begin{array}{c}\text { Jumlah Pengeluaran } \\
(\mathrm{Rp} / \mathrm{minggu})\end{array}$ \\
\hline Daging Sapi & 0,669 & 115.000 & 68.800 \\
Daging Unggas & 2,118 & 29.000 & 52.423 \\
Ikan & 1,117 & 22.370 & 18.893 \\
\hline
\end{tabular}

Sumber: Hasil Penelitian 2018 
Tabel 3. Rata-rata pengeluaran total, pengeluaran pangan dan non pangan dan pangsa pengeluaran pangan dan non pangan terhadap pengeluaran total rumahtangga sebulan menurut strata pendapatan

\begin{tabular}{lcrrcc}
\hline \multirow{2}{*}{ Strata Pendapatan } & \multicolumn{3}{c}{ Rata-rata Pengeluaran (Rp/Bulan) } & \multicolumn{2}{c}{ Pangsa Pengeluaran (\%) } \\
\cline { 2 - 6 } & Total Pengeluaran & \multicolumn{1}{c}{ Pangan } & Non Pangan & Pangan & Non Pangan \\
\hline Rendah & 1.255 .583 & 870.680 & 384.903 & 69 & 31 \\
Sedang & 2.863 .430 & 1.740 .136 & 1.123 .294 & 61 & 39 \\
Tinggi & 8.300 .424 & 2.131 .669 & 6.168 .755 & 26 & 74 \\
Sumatera Barat & 3.630 .939 & 1.717 .716 & 1.913 .224 & 47 & 53 \\
\hline
\end{tabular}

Sumber: Hasil Penelitian 2018

Tabel 4. Permintaan daging berdasarkan jumlah anggota rumahtangga

\begin{tabular}{|c|c|c|c|c|c|}
\hline \multirow{2}{*}{ No } & \multirow{2}{*}{$\begin{array}{l}\text { Anggota RT } \\
\text { (orang) }\end{array}$} & \multirow{2}{*}{$\begin{array}{c}\text { Jumlah } \\
\text { Rumahtangga }\end{array}$} & \multicolumn{2}{|c|}{ Pangsa Pengeluaran (\%) } & \multirow{2}{*}{$\begin{array}{c}\text { Rata-rata Konsumsi Daging } \\
\text { (gr/kapita/minggu) }\end{array}$} \\
\hline & & & Pangan & Non-Pangan & \\
\hline 1 & $\leq 3$ & 41 & 51 & 49 & 67,20 \\
\hline 2 & $4-5$ & 42 & 55 & 45 & 56,32 \\
\hline 3 & $\geq 6$ & 17 & 68 & 32 & 54,33 \\
\hline
\end{tabular}

Sumber: Hasil Penelitian 2018

antara pangan dan non-pangan juga cenderung seimbang, dikarenakan kebutuhan untuk pangan yang telah terpenuhi maka pengeluaran tadi dialihkan untuk memenuhi kebutuhan non-pangan. Tetapi jumlah ratarata daging yang dikonsumsi justru lebih tinggi dibandingkan rumahtangga dengan jumlah anggota rumahtangga yang banyak dikarenakan jumlah daging yang dibeli hanya dikonsumsi oleh sedikit jumlah anggota rumahtangga.

\section{d. Umur Ibu Rumahtangga}

Umur ibu rumahtangga diduga berpengaruhterhadappermintaanrumahtangga terhadap daging seperti penelitian terdahulu yang memasukkan variabel umur ibu rumahtangga yaitu Ariningsih (2004). Variasi umur ibu rumahtangga dari $\leq 30-\geq 61$ tahun, dan dapat dikelompokkan menjadi lima kelompok umur (Tabel 5).

Rata - rata konsumsi daging terbesar terdapat pada ibu dengan rentang umur 5160 tahun dan yang terendah terdapat pada ibu dengan rentang umur $\leq 30$ tahun. Hal ini diduga umur dengan usia produktif cenderung memiliki kegiatan yang membuat ibu tidak sempat mempersiapkan daging untuk dikonsumsi pada rumahtangga karena dapat kita lihat semakin tinggi umur ibunya maka semakin tinggi juga rata - rata konsumsi daging.

e. Pendidikan Ibu Rumahtangga

Indikator pendidikan ibu rumah tangga pada penelitian ini ditentukan atas ibu. Tingkat pendidikan dikelompokkan atas berpendidikan tinggi dan berpendidikan rendah, untuk ibu yang berpendidikan tinggi dibatasi pada ibu yang lulus atau menyelesaikan pendidikan setingkat Perguruan Tinggi, sedangkan untuk ibu dengan berpendidikan rendah dibatasi pada ibu yang lulus atau hanya meneyelesaikan pendidikan dibawah tingkat Perguruan Tinggi (Tabel 6).

Ibu rumah tangga di Provinsi Sumatera Barat sebanyak 58 rumah tangga (58\%) masih memiliki tingkat pendidikan yang rendah dan sebanyak 42 rumah tangga (42\%) ibu rumah tangga berpendidikan tinggi. Ibu rumah tangga dengan berpendidikan tinggi memiliki jumlah konsumsi daging jauh lebih 
Tabel 5. Permintaan daging berdasarkan usia ibu

\begin{tabular}{|c|c|c|c|c|c|}
\hline \multirow{2}{*}{ No } & \multirow{2}{*}{ Umur (tahun) } & \multirow{2}{*}{ Jumlah RT } & \multicolumn{2}{|c|}{ Pangsa Pengeluaran (\%) } & \multirow{2}{*}{$\begin{array}{c}\text { Rata-rata Konsumsi Daging } \\
\text { (gr/kapita/minggu) }\end{array}$} \\
\hline & & & Pangan & Non-Pangan & \\
\hline 1 & $\leq 30$ & 7 & 54 & 46 & 52 \\
\hline 2 & $31-40$ & 34 & 55 & 45 & 56 \\
\hline 3 & $41-50$ & 44 & 57 & 43 & 58 \\
\hline 4 & $51-60$ & 11 & 59 & 41 & 62 \\
\hline 5 & $\geq 61$ & 4 & 52 & 48 & 61 \\
\hline
\end{tabular}

Sumber: Hasil Penelitian 2018

Tabel 6. Permintaan daging berdasarkan tingkat pendidikan ibu

\begin{tabular}{|c|c|c|c|c|c|}
\hline \multirow{2}{*}{ No } & \multirow{2}{*}{$\begin{array}{l}\text { Tingkat } \\
\text { Pendidikan }\end{array}$} & \multirow{2}{*}{ Jumlah RT } & \multicolumn{2}{|c|}{ Pangsa pengeluaran (\%) } & \multirow{2}{*}{$\begin{array}{c}\text { Rata-rata Konsumsi Daging } \\
(\mathrm{gr} / \mathrm{kapita} / \mathrm{minggu})\end{array}$} \\
\hline & & & Pangan & Non-Pangan & \\
\hline 1 & Tinggi & 42 & 53 & 47 & 77,34 \\
\hline 2 & Rendah & 58 & 64 & 36 & 46,04 \\
\hline
\end{tabular}

Sumber: Hasil Penelitian 2018

besar dibandingkan ibu rumah tangga dengan berpendidikan rendah yaitu $77,34 \mathrm{gram} / \mathrm{RT} /$ minggu dan 46,04 gram/RT/minggu.

Penelitian yang sejenis juga dilakukan oleh Budiwinarto (2009) yang menyatakan bahwa semakin baik tingkat pendidikan istri atau wanita dalam rumahtangga akan memberikan dampak yang positif terhadap peningkatan pendapatan dan konsumsi.

f. Wilayah Tempat Tinggal Rumahtangga

Wilayah tempat tinggal rumahtangga pada penelitian ini dibagi atas wilayah perkotaan dan wilayah perdesaan (Tabel 7). Rata-rata konsumsi daging tertinggi terdapat pada rumahtangga di wilayah perkotaan yaitu sebesar 79,13 gr/kapita/ minggu sedangkan pada rumahtangga di wilayah perdesaan hanya $45,89 \mathrm{gr} / \mathrm{kapita} /$ minggu. Untuk pangsa pengeluaran juga dapat disimpulkan rumahtangga di wilayah perdesaan menggunakan $64 \%$ pendapatan rumahtangga untuk memenuhi kebutuhan pangan dan hanya menggunakan $36 \%$ total pengeluaran untuk kebutuhan non-pangan, sebaliknya pada rumahtangga di wilayah perkotaan pengluaran untuk kebutuhan untuk pangan hanya $47 \%$ dari total pengeluaran dan sisanya dialokasikan untuk kebutuhan nonpangan sebesar $53 \%$.

Secara teoritis faktor wilayah diduga berpengaruh terhadap pola konsumsi terutama untuk komoditas pengan asal hewani dikarenakan masyarakat di perkotaan diduga memiliki tingkat pendapatan dan tingkat pendidikan yang lebih baik dibandingkan masyarakat yang tinggal di wilayah perdesaan.

Faktor-Faktor yang mempengaruhi Permintaan Daging Sapi, Unggas dan Ikan pada Rumahtangga di Propinsi Sumatera Barat

Pada model Almost Ideal Demand System, untuk melihat bagaimana model dapat diterima dalam penelitian ini adalah dengan memperhatikan nilai koefisien determinasi sistem $\mathrm{R}^{2}$ yang diperoleh dari hasil pendugaan model dengan metode Ordinary Least Squares (OLS) sebesar 0.8233, artinya sebesar $82.33 \%$ keragaman dalam proporsi pengeluaran setiap pangan hewani yang dapat dijelaskan oleh variabel bebas didalam model, yaitu variabel harga ikan, harga daging sapi, harga daging unggas, total pengeluaran rumahtangga, jumlah anggota rumahtangga, umur ibu rumahtangga, dummy pendidikan 
Tabel 7. Permintaan daging berdasarkan wilayah tempat tinggal rumahtangga

\begin{tabular}{clcccc}
\hline \multirow{2}{*}{ No } & Wilayah Tempat & \multirow{2}{*}{ Jumlah RT } & \multicolumn{2}{c}{ Pangsa Pengeluaran (\%) } & Rata-rata Konsumsi Daging \\
\cline { 3 - 4 } & Tinggal & & Pangan & Non-Pangan & \\
\hline 1 & Pr/kapita/minggu) & 79,13 \\
2 & Perkotaan & 40 & 47 & 53 & 45,89 \\
\hline
\end{tabular}

Sumber: Hasil Penelitian 2018

Tabel 8. Koefisien dugaan variabel model AIDS untuk masing-masing daging

\begin{tabular}{lccc}
\hline Variabel & Ikan & Daging Sapi & Daging Unggas \\
\hline Intersep & $0.331455^{*}$ & $0.090702^{*}$ & $0.149252^{*}$ \\
Harga ikan & $0.063453^{*}$ & $-0.01101^{*}$ & $-0.01554^{*}$ \\
Harga daging sapi & $-0.01101^{*}$ & $0.027165^{*}$ & $-0.00867^{*}$ \\
Harga daging unggas & $-0.01554^{*}$ & $-0.00867^{*}$ & $0.034777^{*}$ \\
Pendapatan & $5.00 \mathrm{E}-10$ & $1.36 \mathrm{E}-08^{*}$ & $-1.25 \mathrm{E}-08$ \\
Jumlah anggota RT & $0.019041^{* *}$ & -0.00401 & $-0.01144^{* *}$ \\
Umur ibu RT & 0.000047 & 0.000548 & 0.000422 \\
Pendidikan ibu RT & -0.00518 & $-0.00382^{*}$ & -0.00128 \\
Wilayah tempat tinggal & -0.01078 & 0.007857 & 0.027293 \\
\hline
\end{tabular}

Sumber: Hasil Penelitian 2018

Keterangan: *: signifikan pada taraf $10 \%$, **: signifikan pada taraf $5 \%$

ibu rumahtangga (berpendidikan tinggi, berpendidikan rendah), variabel dummy wilayah (perkota, pedesaan). Selain itu kriteria statistik yang dapat dilihat untuk mengevaluasi hasil estimasi model persamaan AIDS adalah root-MSE. Nilai root-MSE yang diperoleh 0.1767 , artinya nilai error yang mungkin terjadi pada model adalah $17.67 \%$.

Selanjutnya, pengujian model permintaanjuga dilakukan secaraindividu(satu per satu dari variabel bebas) dengan metode Seemingly Unrelated Regression (SUR) untuk mengetahui apakah masing-masing variabel besar signifikan mempengaruhi variabel tak bebas. Tabel 8 menyajikan koefisien dugaan variabel model AIDS untuk masing-masing pangan hewani.

Uji Signifikansi Model (Uji Statistik F)

Uji Statistik F merupakan uji signifikansi model secara simultan yang menunjukkan apakah peubah bebas pada model mempunyai pengaruh secara bersama- sama terhadap peubah tak bebas. Uji F yang signifikan menunjukkan model dapat diterima dan nilai elastisitas yang diperoleh lebih akurat. Analisis model Almost Ideal Demand System (AIDS) dengan menggunakan software SAS (Gambar 1).

\section{KESIMPULAN}

Berdasarkan dari hasil penelitian yang telah dilakukan maka dapat diambil kesimpulan bahwa:

1. Pola konsumsi daging sapi, daging unggas dan ikan pada rumahtangga di Propinsi Sumatera Barat menunjukkan bahwa variable ekonomi yaitu harga mempengaruhi jumlah konsumsi masing masing komoditi daging dan rata - rata pengeluaran setiap bulan juga mempengaruhi jumlah konsumsi daging pada rumahtangga tersebut. Untuk variabel sosiodemografi menunjukkan semakin 


$$
\begin{array}{r}
w_{1}=0.3315-0.0369 \log p_{1}+0.0635 \log p_{2}-0.0110 \log p_{3}-0.0155 \log p_{3}-0.0393 \log \left(\frac{x}{p}\right) \\
\quad-0.0108 W-0.0052 P d d k+0.000047 U+0.0190 J+5.00 \mathrm{E}-10 T-1.20 \mathrm{E}-08 P M \\
w_{2}=0.0907-0.0075 \log p_{1}-0.0110 \log p_{2}+0.0272 \log p_{3}-0.0087 \log p_{3}+0.0158 \log \left(\frac{x}{p}\right) \\
+0.0076 W-0.0038 P d d k+0.00055 U-0.0040 J+1.36 \mathrm{E}-08 T+1.08 \mathrm{E}-08 P M \\
w_{3}=0.1493-0.0106 \log p_{1}-0.0155 \log p_{2}-0.0087 \log p_{3}+0.0348 \log p_{3}+0.0122 \log \left(\frac{x}{p}\right) \\
+0.0273 W-0.0013 P d d k+0.00042 U-0.0114 J-1.25 \mathrm{E}-08 T+4.23 \mathrm{E}-08 P M
\end{array}
$$

Keterangan:

$w_{1} \quad$ : Proporsi pengeluaran untuk komoditi ikan

$w_{2} \quad$ : Proporsi pengeluaran untuk komoditi daging sapi

$w_{3} \quad$ : Proporsi pengeluaran untuk komoditi daging unggas

$p_{1} \quad$ : Harga komoditi ikan (dalam Rupiah)

$p_{2} \quad$ : Harga komoditi daging sapi (dalam Rupiah)

$p_{3} \quad$ : Harga komoditi daging unggas (dalam Rupiah)

$x \quad$ : Total pengeluaran untuk komiditi telur, ikan, daging sapi, dan daging unggas

$P \quad$ : Indeks harga stone

$W \quad$ : Wilayah $(1=$ kota, $0=$ desa $)$

$P d d k$ : Pendidikan ibu rumah tangga $(1=$ berpendidikan tinggi; $0=$ berpendidikan rendah $)$

$U \quad$ : Umur ibu rumah tangga

$J \quad$ : Jumlah anggota rumah tangga

$T \quad$ : Total Pengeluran

$P M \quad$ : Pengeluaran untuk makanan

\section{Gambar 1. Analisis model Almost Ideal Demand System (AIDS)}

tinggi jumlah anggota keluarga maka jumlah konsumsi rumah tangga tersebut juga semakin meningkat, perbedaan umur ibu tidak memiliki pengaruh terhadap jumlah konsumsi daging, pada tingkat Pendidikan ibu menunjukkan jika ibu memiliki tingkat pendidikan yang tinggi maka jumlah konsumsi juga akan meningkat dibandingkan ibu dengan tingkat pendidkan yang rendah dan untuk wilayah tempat tinggal rumahtangga juga memperlihatkan rumahtangga yang menempati wilayah perkotaan akan memiliki rata - rata konsumsi yang lebih tinggi dibandingkan dengan rumahtangga yang menempati wilayah pedesaan.

2. Model dari permintaan daging sapi, daging unggas dan ikan ditandai dengan $\mathrm{R}^{2}$ sebesar 0.8233 , artinya $82.33 \%$. Faktor - faktor yang mempengaruhi permintaan daging pada penelitian ini dibagi atas tiga tingkatan signifikasi yaitu:

a. Variabel siginifikan pada taraf $10 \%$ adalah harga masing - masing komoditas yang berupa daging sapi, daging ayam dan ikan, total pengeluaran rumahtangga dan tingkat pendidikan ibu rumahtangga (dummy pendidikan tinggi dan pendidikan rendah).

b. Variabel yang signifikan pada tarah $5 \%$ adalah jumlah anggota rumahtangga.

c. Variabel yang tidak berpengaruh terhadap permintaan daging adalah umur ibu rumahtangga dan wilayah tempat tinggal rumahtangga (perkotaan dan pedesaan). 


\section{DAFTAR PUSTAKA}

Ariningsih, E. 2004. Analisis Perilaku Konsumsi Pangan Sumber Protein Hewani dan Nabati Pada Masa Krisis Ekonomi di Jawa. Pusat Penelitian dan Pengembangan Sosial Ekonomi Pertanian. 2004.

Badan Perencanaan dan Pembangunan Nasional. 2011. Rencana Aksi Nasional Pangan dan Gizi 2011 - 2015. Kementrian Perencanaan Pembangunan Nasional (BAPPENAS). Jakarta.

Badan Pusat Statistik (BPS) Propinsi Sumatera Barat. 2018. Sumatera Barat Dalam Angka Tahun 2017. Padang.

Budiwinarto, K. 2006. Penerapan Model Almost Ideal Demand System (AIDS) pada Pola Konsumsi Pangan Rumahtangga Nelayan di Kecamatan
Tambak Kabupaten Banyumas, Fakultas Ekonomi Universitas Surakarta.

Deaton. M. and J. Muellbauer. 1980. An Almost Ideal Demand System. American Economic Review 70 no 3 (Jun 1980). Pp. 312-326. American Economic Association.

Hardjosworo dan Rukminasih. 2000. Peningkatan Produksi Ternak Unggas. Penebar Swadaya. Jakarta.

Jafrinur., J. Yusri, dan R. Wati. 2009. Pengembangan model fungsi konsumsi untuk komoditi pangan hewani (Kasus Kota Padang Propinsi Sumatera Barat). Laporan hasil penelitian fundamental. DP2M Dikti. Universitas Andalas, Padang. 